\title{
OncomiRs: the discovery and progress of microRNAs in cancers William CS Cho
}

Address: Department of Clinical Oncology, Queen Elizabeth Hospital, Room 1305, 13/F, Block R, 30 Gascoigne Road, Kowloon, Hong Kong SAR, PR China

Email: William CS Cho - chocs@ha.org.hk

Published: 25 September 2007

Received: 6 July 2007

Molecular Cancer 2007, 6:60 doi:10.1 186/1476-4598-6-60

Accepted: 25 September 2007

This article is available from: http://www.molecular-cancer.com/content/6/1/60

(c) 2007 Cho; licensee BioMed Central Ltd.

This is an Open Access article distributed under the terms of the Creative Commons Attribution License (http://creativecommons.org/licenses/by/2.0), which permits unrestricted use, distribution, and reproduction in any medium, provided the original work is properly cited.

\begin{abstract}
microRNAs (miRNAs) are evolutionarily conserved, endogenous, small, noncoding RNA molecules of about 22 nucleotides in length that function as posttranscriptional gene regulators. They are deemed to play a crucial role in the initiation and progression of human cancer, and those with a role in cancer are designated as oncogenic miRNAs (oncomiRs). For example, miR-15 and miR-16 induce apoptosis by targeting $B C I 2$. miRNAs from the miR-I 7-92 cluster modulate tumor formation and function as oncogenes by influencing the translation of E2FI mRNA. miR-2I modulates gemcitabine-induced apoptosis by phosphatase and tensin homolog deleted on chromosome 10dependent activation of PI 3-kinase signaling. miR-34a acts as a suppressor of neuroblastoma tumorigenesis by targeting the mRNA encoding E2F3 and reducing E2F3 protein levels. The chromosomal translocations associating with human tumors disrupt the repression of High mobility group A2 by let-7 miRNA. In addition, the oncomiRs expression profiling of human malignancies has also identified a number of diagnostic and prognostic cancer signatures. This article introduces the roles of oncomiRs in neoplasm development, progression, diagnosis, prognostication, as well as their mechanism of actions on target mRNAs and the functional outcomes of their actions on mRNAs. The paper ends with a brief perspective to the future of oncomiRs.
\end{abstract}

\section{Introduction}

microRNAs (miRNAs) are evolutionarily conserved, endogenous, small, noncoding RNA molecules of about 22 nucleotides in length that function as posttranscriptional gene regulators [1]. They are encoded in the genome and are generally transcribed by RNA polymerase II. miRNAs work via RNA-induced silencing complexes, targeting them to messenger RNAs where they either repress translation or direct destructive cleavage [2]. Recent evidences have shown that miRNAs have diverse functions, including the regulation of cellular development, differentiation, proliferation and apoptosis. The first miRNA was described in 1993, in which the C. elegans heterochronic gene lin-4 encoded small RNAs with anti- sense complementarity to lin-14 [3]. It is estimated that vertebrate genomes encode up to 1,000 unique miRNAs [4], which are predicted to regulate expression of at least $30 \%$ of genes [5]. Though more than 530 miRNAs have been identified in human, much remains to be understood about their precise cellular function and role in the development of diseases. Recent evidences indicate that miRNAs can function as tumor suppressors and oncogenes, and the miRNAs with a role in cancer are designated as oncogenic miRNAs (oncomiRs). This article introduces the roles of oncomiRs in neoplasm development, progression, diagnosis, prognostication, as well as their mechanism of actions on target mRNAs and the functional outcomes of their actions on mRNAs. 


\section{microRNAs experiment}

miRNA microarray is a high-throughput approach to study the expression of miRNAs in cultured cells or tissues. Unlike the traditional cDNA microarray expression profiling, RNA samples used for miRNA microarray hybridization need to be enriched for small RNAs. Usually, the first step of a miRNA microarray experiment is the isolation of total RNA and the enrichment or direct isolation of small RNA. The miRNAs are then labeled and cleaned-up, following with miRNA hybridization to arrays spotted with miRNA probes. After washes and scanning, the differential miRNAs are identified. Subsequent validation is recommended using Northern blot, quantitative reverse transcription-polymerase chain reaction (qRT-PCR), or other analytical methods. The recent development of highly efficient labeling method and novel microarray probe design enable direct label as low as 120 ng of total RNA using Cy3 or Cy5, without fractionation or amplification, to produce precise and accurate measurements that span a linear dynamic range from 0.2 amol to $2 \mathrm{fmol}$ of input miRNA. The assay is also applicable for formalin-fixed paraffin-embedded samples [6].

\section{microRNAs and cancers}

It has been reported that miRNAs play a crucial role in the initiation and progression of human cancer. Deregulation of oncomiRs is associated with genetic or epigenetic alterations, including deletion, amplification, point mutation and aberrant DNA methylation [7]. Their expression profiling of human malignancies has identified signatures involving in cancer development, progression, diagnosis and prognosis (Table 1).

\section{The role of microRNAs in tumorigenesis}

Calin et al. first made the connection between microRNAs and cancer by showing that $m i R-15$ and $m i R-16$ are located at chromosome $13 q 14$, a region deleted in more than half of B-cell chronic lymphocytic leukemia (CLL). Detailed deletion and expression analysis showed that $m i R-15$ and $m i R-16$ are located within a $30 \mathrm{~kb}$ region of loss in CLL, and that both genes were deleted or downreg-

Table I: The role of microRNAs in cancers

\begin{tabular}{|c|c|c|c|}
\hline microRNAs & Tumorigenesis & Diagnosis & Prognosis \\
\hline $\operatorname{miR}-9$ & Neuroblastoma & & \\
\hline $\operatorname{miR}-10 b$ & Breast cancer & & \\
\hline $\operatorname{miR}-15, \operatorname{miR}-15 a$ & Leukemia, pituitary adenoma & & \\
\hline miR-I6, miR-I6-I & Leukemia, pituitary adenoma & & \\
\hline miR-I 7-5p, miR-I 7-92 & Lung cancer, lymphoma & & \\
\hline $\operatorname{miR}-20 a$ & Lymphoma, lung cancer & & \\
\hline $\operatorname{miR}-2 I$ & $\begin{array}{l}\text { Breast cancer, cholangiocarcinoma, head \& neck } \\
\text { cancer, leukemia, cervical cancer }\end{array}$ & & Pancreatic cancer \\
\hline miR-29, miR-29b & Leukemia, cholangiocarcinoma & & \\
\hline miR-3I & Colorectal cancer & & \\
\hline $\operatorname{miR}-34 a$ & Pancreatic cancer & & Neuroblastoma \\
\hline $\operatorname{miR}-96$ & Colorectal cancer & & \\
\hline $\operatorname{miR}-98$ & Head \& neck cancer & & \\
\hline miR- 103 & Pancreatic cancer & & \\
\hline $\operatorname{miR}-107$ & Leukemia, pancreatic cancer & & \\
\hline miR-I25a, miR-I25b & Neuroblastoma, breast cancer & & \\
\hline $\operatorname{miR}-128$ & Glioblastoma & & \\
\hline $\operatorname{miR}-133 b$ & Colorectal cancer & & \\
\hline $\operatorname{miR}-135 b$ & Colorectal cancer & & \\
\hline miR-I43 & Colon cancer, cervical cancer & & \\
\hline $\operatorname{miR}-145$ & Breast cancer, colorectal cancer & & \\
\hline $\operatorname{miR}-146$ & Thyroid carcinoma & & \\
\hline $\operatorname{miR}-155$ & Breast cancer, leukemia, pancreatic cancer & & Lung cancer \\
\hline $\operatorname{miR}-I 8 I, \operatorname{miR}-I 8 I a, m i R-I 8 I b, \operatorname{miR}-I 8 I \mathrm{c}$ & Leukemia, glioblastoma, thyroid carcinoma & & \\
\hline $\operatorname{miR}-183$ & Colorectal cancer & & \\
\hline $\operatorname{miR}-184$ & Neuroblastoma & & \\
\hline miR-196a-2 & & & Pancreatic cancer \\
\hline $\operatorname{miR}-221$ & Glioblastoma, thyroid carcinoma & Pancreatic cancer & \\
\hline $\operatorname{miR}-222$ & Thyroid carcinoma & & \\
\hline $\operatorname{miR}-223$ & Leukemia & & \\
\hline miR-30I & & Pancreatic cancer & \\
\hline $\operatorname{miR}-376$ & & Pancreatic cancer & \\
\hline let-7, let-7a, let-7a-I, hsa-let-7a-2, let-7a-3 & Lung cancer, colon cancer & & Lung cancer \\
\hline
\end{tabular}


ulated in approximately $68 \%$ of CLL cases [8]. They further showed that miR genes were frequently located in cancer-associated genomic regions or in fragile sites. The full complement of miRNAs in a genome might be extensively involved in cancers [9]. Bottoni et al. found that miR-15a and miR-16-1 were expressed at lower levels in pituitary adenomas as compared to normal pituitary tissue. Their expression was inversely correlated with tumor diameter and with arginyl-tRNA synthetase expression, but was directly correlated with $p 43$ secretion, suggesting that these miRNAs might influence tumor growth [10]. Cimmino et al. then demonstrated that $m i R-15 a$ and $m i R$ 16-1 expressions were inversely correlated to Bcl2 expression in CLL and that both miRNAs negatively regulated $B c l 2$ at a posttranscriptional level. $B c l 2$ repression by these miRNAs induced apoptosis in a leukemic cell line model. Therefore $m i R-15$ and $m i R-16$ were natural antisense $B c l 2$ interactors that could be used for therapy of $B c l 2$-overexpressing tumors [11]. Recently, Garzon et al. showed that all-trans retinoic acid (ATRA) downregulation of $\mathrm{Bcl} 2$ and Ras was correlated with the activation of $m i R-15 a / m i R-16-$ 1 [12].

Amplification and overexpression of the miR-17-92, which comprised 7 miRNAs and resided in intron 3 of the C13orf25 gene at 13q31.3, has been reported with pointers to functional involvement in the development of lymphoma and lung cancer. He et al. compared B-cell lymphoma samples and cell lines to normal tissues, and found that the levels of the primary or mature miRNAs derived from the miR-17-92 locus were often substantially increased in cancer cells. Their studies indicated that miRNAs could modulate tumor formation and function as oncogenes, implicating the miR-17-92 cluster as a potential human oncomicroRNAs (oncomiRs) [13]. O'Donnell et al. demonstrated that c-Myc activated expression of a set of 6 miRNAs on human chromosome 13 that was tied to the development of human lymphoma. It was found that the expression of E2F1 was negatively regulated by $m i R$ 17-5p and miR-20a in HeLa cells. Their findings revealed a mechanism through which the c-Myc protein simultaneously activated E2F1 transcription and limited its translation, allowing a tightly controlled proliferative signal [14]. Woods et al. proposed a model whereby miR-17-92 promoted cell proliferation by shifting the E2F transcriptional balance away from the pro-apoptotic E2F1 and toward the proliferative E2F3 transcriptional network [15].

On the other hand, Hayashita et al. found that miR-17-92 was markedly overexpressed in lung cancer, especially with small-cell lung cancer. Their findings suggested that marked overexpression of the miR-17-92 cluster with occasional gene amplification might play a role in the development of lung cancer and that the C13orf25 gene might well be serving as a vehicle in this regard [16]. Matsubara $e t$ al. showed that inhibition of $m i R-17-5 p$ and $m i R$ $20 a$ with antisense oligonucleotides could induce apoptosis selectively in lung cancer cells overexpressing $m i R-17$ 92, suggesting the possibility of oncomiR addiction to expression of these miRNAs in a subset of lung cancers. Their discoveries contributed towards better understanding of the oncogenic roles of miR-17-92, which might ultimately lead to the future translation into clinical applications [17].

Iorio et al. showed that miRNAs were aberrantly expressed in human breast cancer compared with normal breast tissue, with the most significantly downregulated miRNAs being $m i R-10 b, m i R-125 b$ and $m i R-145$, whereas the most significantly upregulated miRNAs being $m i R-21$ and $m i R$ 155. The miRNA expression was also found to be correlated with specific breast cancer biopathologic features, such as estrogen and progesterone receptor expression, tumor stage, vascular invasion or proliferation index [18]. Si $e t$ al. found that miR-21 was highly overexpressed in breast tumors compared to the matched normal breast tissues. They found that the anti-miR-21-mediated cell growth inhibition was associated with increased apoptosis and decreased cell proliferation. Their results suggested that $m i R-21$ functioned as an oncogene and modulated tumorigenesis through regulation of genes such as $\mathrm{Bcl} 2$ and it might serve as a novel therapeutic target [19]. Zhu et al. performed two-dimensional differentiation in-gel electrophoresis of tumors treated with anti-miR-21 and identified the tumor suppressor tropomyosin 1 as a potential miR-21 target. Downregulation of tropomyosin 1 in breast cancer by miR-21 might explain why suppression of miR-21 could inhibit tumor growth, further supporting the notion that $m i R-21$ functions as an oncogene [20]. Meng et al. identified miR-21 was also highly overexpressed in malignant cholangiocytes. Inhibition of miR-21 increased sensitivity to gemcitabine, it modulated gemcitabine-induced apoptosis by phosphatase and tensin homolog deleted on chromosome 10-dependent activation of PI 3-kinase signaling [21]. Tran et al. found that $m i R-21$ was highly expressed in the head and neck cancer cell lines. Several tumor suppressor genes were identified to be potential targets of miRNAs, including kinesin family member $1 \mathrm{~B}$ isoform alpha, hypermethylated in cancer 2 and pleomorphic adenoma gene 1 [22].

Costinean $e$ al. showed that E(mu)-mmu-miR-155 transgenic mice exhibited preleukemic pre-B-cell proliferation evident in spleen and bone marrow, followed by frank Bcell malignancy. Their findings indicated that miR-155 could induce polyclonal expansion, favoring the capture of secondary genetic changes for full transformation [23]. Using miRNA cloning and qRT-PCR of mature miRNAs, Fulci et al. demonstrated that miR-21 and miR-155 were 
dramatically overexpressed in CLL patients [24]. Besides, Roldo et al. showed that the expression of $m i R-103$ and $m i R-107$, associating with a lack of $m i R-155$ expression, could discriminate pancreatic tumors from normal pancreas. Their results suggested that the alteration in miRNA expression was related to endocrine and acinar neoplastic transformation [25].

Felli et al. demonstrated that treatment of CD34+ progenitors with $m i R-221$ and $m i R-222$ caused impaired proliferation and accelerated differentiation of erythropoietic cells, coupled with the downmodulation of Kit protein. The decline of $m i R-221$ and $m i R-222$ during exponential erythropoietic growth unblocked Kit protein production at mRNA level, thus leading to expansion of early erythroblasts [26]. He et al. also showed that $m i R-146, m i R-221$ and $m i R-222$ distinguished unequivocally between papillary thyroid carcinoma (PTC) and normal thyroid. The upregulation of these miRNAs was strongest associated with a dramatic loss of Kit transcript and its protein. Sequence changes in genes targeted by these miRNAs could contribute to the regulation of Kit involved in PTC pathogenesis [27]. Analyzing the genome-wide miRNA expression profile in human PTCs using microarray, Pallante et al. detected a significant increase of $m i R-181 b$, $m i R-221$ and $m i R-222$ in the comparison of PTCs with normal thyroid tissue. Further confirmation by Northern blot analysis and qRT-PCR, their results suggested miRNA deregulation as an important event in thyroid cell transformation [28].

The analysis of both glioblastoma tissues and glioblastoma cell lines allowed Ciafre et al. to identify a group of miRNAs whose expression was significantly altered in the tumor. $m i R-221$ was strongly upregulated, whereas $m i R$ 128, $m i R-181 a, m i R-181 b$ and $m i R-181 c$ were downregulated in glioblastoma [29]. Pekarsky et al. discovered that the expression levels of $m i R-29$ and $m i R-181$ were inversely correlated with Tcl1 expression in CLL. Their results showed that $m i R-29$ and $m i R-181$ might be candidates for therapeutic agents in CLL overexpressing Tcl1 [30]. By in silico analysis, Mott et al. identified a putative target site in the Mcl1 mRNA and found that miR-29b was downregulated in malignant cells, consistent with Mcl1 protein upregulation. Enforced $m i R-29 b$ expression reduced $\mathrm{Mcl} 1$ protein expression in the $\mathrm{KMCH}$ cholangiocarcinoma cells, thus $m i R-29$ was an endogenous regulator of Mcl1 protein expression [31].

Examined by RT-PCR, Bandres et al. identified 13 significantly deregulated mature miRNAs in colorectal cancer, including $m i R-31, m i R-96, m i R-133 b, m i R-135 b, m i R-145$ and $m i R-183$. In addition, the expression level of $m i R-31$ was correlated with the stage of colorectal cancer [32]. Akao et al. found that miR-143 and miR-145 expression levels were extremely reduced in the colon cancer cells. The transfection of each precursor miRNA into the cells demonstrated a significant growth inhibition in human colon cancer DLD-1 and SW480 cells, whereas Erk5 was determined to be the target gene of $m i R-143$ [33].

Laneve et al. showed that $m i R-9, m i R-125 a$ and $m i R-125 b$ acted in an additive manner by repressing the truncated isoform of the neurotrophin receptor tropomyosinrelated kinase $\mathrm{C}$. They found that the downregulation of this isoform was critical for regulating neuroblastoma cell growth [34].In vitro functional studies of neuroblastoma cell lines indicated that $m i R-184$ played a significant role in apoptosis. Chen and Stallings suggested that neuroblastoma derived $M y c$ myelocytomatosis viral related oncogene might mediate a tumorigenic effect through directly or indirectly regulating the expression of miRNAs that were involved with neural cell differentiation and/or apoptosis [35].

Welch et al. showed that miR-34a on chromosome 1p36.23 was generally expressed at lower levels in unfavorable primary neuroblastoma tumors relative to normal tissue. miR-34a directly targeted the mRNA encoding E2F3 and significantly reduced E2F3 protein levels. Their results suggested that $m i R-34 a$ acted as a suppressor of neuroblastoma tumorigenesis [36]. Chang et al. showed that miR$34 a$ was frequently absent in pancreatic cancer cells. They demonstrated that this miRNA was directly transactivated by $p 53$. miR-34a-responsive genes were highly enriched for those that regulated cell-cycle progression, apoptosis, DNA repair and angiogenesis. It was likely that an important function of $m i R-34 a$ was the modulation and finetuning of the gene expression program initiated by $p 53$ [37].

Nervi et al. found that the expression level of $m i R-223$ was correlated with the differentiation fate of myeloid precursors. The activation of both pathways of transcriptional regulation by the myeloid lineage-specific transcription factor CCAAT/enhancer-binding protein- $\alpha(\mathrm{C} / \mathrm{EBPa})$ and posttranscriptional regulation by $m i R-223$ appeared essential for granulocytic differentiation and clinical response of acute promyelocytic leukemia blasted to ATRA [38]. Using miRNA microarray platform and qRTPCR, Garzon et al. reported the expression of miRNAs in acute promyelocytic leukemia patients and cell lines during ATRA treatment. They found upregulation of $m i R-107$ targeted nuclear factor $1-\mathrm{A}$, a gene involving $m i R-223$ and $\mathrm{C} / \mathrm{EBPa}$ in a regulatory loop during granulocytic differentiation. Besides, ATRA downregulation of Ras and $\mathrm{Bcl} 2$ was shown to correlate with the activation of let-7a miRNA [12]. 
Johnson et al. showed that the let-7 miRNA family negatively regulated let-60/Ras. Loss of let-60/Ras suppressed let-7 miRNA complementary sites, restricting reporter gene expression in a let-7-dependent manner. let-7 miRNA expression was lower in lung tumors than in normal lung tissue, while Ras protein was significantly higher in lung tumors, providing a possible mechanism for let-7 miRNA in cancer [39]. Akao et al. found that the levels of Ras and c-Myc proteins in let-7 miRNA low-expressing DLD-1 human colon cancer cells were lowered after the transfection with let-7a-1 precursor miRNA, whereas the levels of both of their mRNAs remained almost unchanged. Their findings suggested the involvement of let-7 miRNA in the growth of colon cancer cells [40]. Meng et al. demonstrated that let-7a miRNA was upregulated and contributed to the survival effects of enforced Interleukin-6 activity in malignant human cholangiocytes. It contributed to the constitutively increased phosphorylation of the signal transducers and activators of transcription-3 factors by a mechanism involving neurofibromatosis 2 [41]. Brueckner et al. showed that the human let-7a-3 precursor miRNA on chromosome 22q13.31 was associated with a CpG island. They identified let-7a-3 precursor miRNA as an epigenetically regulated miRNA gene in lung adenocarcinomas with oncogenic function and suggested that aberrant miRNA gene methylation might contribute to the human cancer epigenome [42].

Mayr et al. reported that the chromosomal translocations associating with human tumors disrupted the repression of High mobility group A2 (Hmga2) by let-7 miRNA. They found that the loss of miRNA-directed repression of an oncogene provided a mechanism for tumorigenesis, and disrupting a single miRNA-target interaction could produce an observable phenotype in mammalian cells [43]. Lee and Dutta also demonstrated that ectopic expression of let-7 miRNA reduced Hmga2 and cell proliferation in lung cancer cell. Their results suggested that some tumors activated the oncogene through chromosomal translocations that eliminated the oncogene's 3' untranslated region with the let-7 miRNA target sites [44]. Hebert et al. reported that Hmga2 expression in head and neck squamous cell carcinoma cells was regulated in part by miR-98. They showed that the transfection of pre-miR-98 during normoxia diminished Hmga2 and potentiate resistance to doxorubicin and cisplatin. Their findings implicated the role of $m i R-98$ as a key element in modulating tumors during hypoxia [45].

Stem cells have the ability to escape cell cycle stop signals, which are similar to cancer cells. On the basis of cell cycle markers and genetic interactions, Harfield et al. reported that dicer-1 mutant germline stem cells were delayed in the G1 to S transition, which was dependent on the cyclindependent kinase inhibitor dacapo, suggesting that miR-
NAs were required for stem cells to bypass the normal G1/ $S$ checkpoint. The miRNA pathway might be part of a mechanism that made stem cells insensitive to environmental signals that normally stop the cell cycle at the G1/ S transition [46].

\section{The role of microRNAs in cancer diagnosis}

Lu et al. used a bead-based flow cytometric miRNA expression profiling method to present a systematic expression analysis of miRNAs from human cancer samples, including colon, liver, pancreas and stomach cancers. The miRNA expression profiles were able to successfully classify poorly differentiated tumors. Their findings highlighted the potential of miRNA profiling in cancer diagnosis [47].

Analyzing the entire miRNAome in pituitary adenomas and in normal pituitary samples by microarray and RTPCR, Bottoni et al. showed that miRNA expression could differentiate micro- from macro-adenomas and the treated from non-treated patient samples. Several miRNAs were involved in cell proliferation and apoptosis. Predictive miRNAs could be potentially useful diagnostic markers, improving the classification of pituitary adenomas [48].

With the application of in situ RT-PCR, Lee et al. showed that the aberrantly expressed miR-221, miR-301 and miR$376 a$ were localized to pancreatic cancer cells but not to stroma or normal acini or ducts. Aberrant miRNA expression offered new clues to pancreatic tumorigenesis and might provide diagnostic biomarkers for pancreatic cancer [49].

\section{The role of microRNAs in cancer prognosis}

Takamizawa et al. reported that expression of let-7 miRNA was frequently reduced in human lung cancers, and that reduced let-7 miRNA expression was significantly associated with shorter postoperative survival. In addition, overexpression of let-7 miRNA in A549 lung adenocarcinoma cell line inhibited lung cancer cell growth in vitro. Their study reported the potential clinical and biological effects of let-7 miRNA alteration [50]. Yanaihara et al. identified miRNA expression profiles which could discriminate lung cancers from noncancerous lung tissues as well as molecular signatures that differed in tumor histology. High hsamiR-155 and low hsa-let-7a-2 precursor miRNA expression were found to be correlated with poor survival of lung adenocarcinomas. Their results indicated that miRNA expression profiles were not just diagnostic markers, but also prognostic markers of lung cancer [51].

Roldo et al. showed that the overexpression of $m i R-21$ in pancreatic tumors was strongly associated with both high Ki67 proliferation index and the presence of liver metasta- 
sis. Their results suggested that the alteration in miRNA expression was related to progression of malignancy [25]. On the other hand, Bloomston et al. compared the expression pattern of miRNAs in pancreatic cancer with those of normal pancreas and chronic pancreatitis using miRNA microarrays. Differentially expressed miRNAs were identified which could differentiate pancreatic cancer from normal pancreas, chronic pancreatitis, or both. High expression of miR-196a-2 was found to predict poor survival [52].

\section{Perspective}

Discovery of the role of miRNAs in various pathological processes has opened up possible applications in molecular diagnostics and prognostics, particularly for cancer. Some miRNAs are controlled by epigenetic alterations in cancer cells, including DNA methylation and histone modification. Using chromatin modifying drugs to activate tumor suppressor miRNAs can regulate target oncogenes, and it may lead to novel cancer therapies in the future. miRNAs can complement other genomic and proteomic biomarkers for cancer diagnosis and prognosis $[53,54]$. Although each miRNA can control hundreds of target genes, it remains a great challenge to identify the accurate miRNA targets for cancer research. On the other hand, as stem cells can regenerate and develop into many different cell types in the body, they are always a focus of intense research interest. It has been reported that miRNA pathway plays a regulatory role in stem cell division, whether this mechanism will contribute to prevent and treat cancer will be worth studying [55].

The Nobel Prize in Physiology or Medicine 2006 was awarded to Andrew Fire and Craig Mello for their discovery of RNA interference (RNAi) - gene silencing by double-stranded RNA. Since regulatory trans-acting antisense RNAs has been found to exist in several species, posttranscriptional regulation of genes is no longer regarded as an odd regulatory mechanism. miRNAs repress their target mRNAs by complementary base pairing and induction of the RNAi pathway. The discovery of hundreds of miRNAs has raised the overall field of biomedical RNAi to a striking level of the current recognition. Attention has been focused on the study of antisense oligonucleotide approaches to inhibit miRNA function and small interfering RNA-like technologies for the replacement of miRNAs. Scientists try to unravel the mystery of miRNA biology and explore its potential as therapeutic agents. Large high-throughput studies in patients have revealed that oncomiRs profiling can classify cancers and predict patient outcomes with high accuracy. High-throughput target analysis combining genomics, miRomics and proteomics might help delineating the spectrum of targets that are regulated by miRNAs. New knowledge about the functional roles of oncomiRs is revolutionizing cancer biology and will open up new opportunities in biomedical research.

\section{References}

I. Lagos-Quintana M, Rauhut R, Lendeckel W, Tuschl T: Identification of novel genes coding for small expressed RNAs. Science 200I, 294:853-858.

2. Meltzer PS: Cancer genomics: small RNAs with big impacts. Nature 2005, 435:745-746.

3. Lee RC, Feinbaum RL, Ambros V: The C.elegans heterochronic gene lin-4 encodes small RNAs with antisense complementarity to lin-14. Cell 1993, 75:843-854.

4. Berezikov E, Guryev V, van de Belt J, Wienholds E, Plasterk RH, Cuppen E: Phylogenetic shadowing and computational identification of human microRNA genes. Cell 2005, I 20:2I-24.

5. Lewis BP, Burge CB, Bartel DP: Conserved seed pairing, often flanked by adenosines, indicates that thousands of human genes are microRNA targets. Cell 2005, I 20: I5-20.

6. Wang $H$, Ach RA, Curry $B$ : Direct and sensitive miRNA profiling from low-input total RNA. RNA 2007, I3:151-159.

7. Calin GA, Croce CM: MicroRNA signatures in human cancers. Nat Rev Cancer 2006, 6:857-866.

8. Calin GA, Dumitru CD, Shimizu M, Bichi R, Zupo S, Noch E, Aldler H, Rattan S, Keating M, Rai K, Rassenti L, Kipps T, Negrini M, Bullrich $F$, Croce CM: Frequent deletions and down-regulation of micro-RNA genes $\mathrm{miR} / 5$ and $\mathrm{miR} / 6$ at I3q I4 in chronic lymphocytic leukemia. Proc Natl Acad Sci USA 2002, 99: I 5524- I5529.

9. Calin GA, Sevignani C, Dumitru CD, Hyslop T, Noch E, Yendamuri S, Shimizu M, Rattan S, Bullrich F, Negrini M, Croce CM: Human microRNA genes are frequently located at fragile sites and genomic regions involved in cancers. Proc Natl Acad Sci USA 2004, I 01 :2999-3004.

10. Bottoni A, Piccin D, Tagliati F, Luchin A, Zatelli MC, degli Uberti EC: miR-I5a and miR-I6-I down-regulation in pituitary adenomas. J Cell Physiol 2005, 204:280-285.

II. Cimmino A, Calin GA, Fabbri M, lorio MV, Ferracin M, Shimizu M, Wojcik SE, Aqeilan RI, Zupo S, Dono M, Rassenti L, Alder H, Volinia S, Liu CG, Kipps TJ, Negrini M, Croce CM: miR-I5 and miR-I6 induce apoptosis by targeting BCL2. Proc Natl Acad Sci USA 2005, I 02: I 3944-13949.

12. Garzon R, Pichiorri F, Palumbo T, Visentini M, Aqeilan R, Cimmino A, Wang H, Sun H, Volinia S, Alder H, Calin GA, Liu CG, Andreeff M, Croce CM: MicroRNA gene expression during retinoic acidinduced differentiation of human acute promyelocytic leukemia. Oncogene 2007, 26:4I48-4I57.

13. He L, Thomson JM, Hemann MT, Hernando-Monge E, Mu D, Goodson S, Powers S, Cordon-Cardo C, Lowe SW, Hannon GJ, Hammond SM: A microRNA polycistron as a potential human oncogene. Nature 2005, 435:828-833.

14. O'Donnell KA, Wentzel EA, Zeller KI, Dang CV, Mendell JT: c-Mycregulated microRNAs modulate E2FI expression. Nature 2005, 435:839-843.

15. Woods K, Thomson JM, Hammond SM: Direct regulation of an oncogenic micro-RNA cluster by E2F transcription factors. J Biol Chem 2007, 282:2 I30-2I34.

16. Hayashita $Y$, Osada H, Tatematsu Y, Yamada H, Yanagisawa K, Tomida S, Yatabe Y, Kawahara K, Sekido Y, Takahashi T: A polycistronic microRNA cluster, miR-I7-92, is overexpressed in human lung cancers and enhances cell proliferation. Cancer Res 2005, 65:9628-9632.

17. Matsubara H, Takeuchi T, Nishikawa E, Yanagisawa K, Hayashita $Y$, Ebi H, Yamada H, Suzuki M, Nagino M, Nimura Y, Osada H, Takahashi $\mathrm{T}$ : Apoptosis induction by antisense oligonucleotides against $m i R-I 7-5 p$ and $m i R-20 a$ in lung cancers overexpressing $m i R-$ I7-92. Oncogene 2007, 26:6099-I05.

18. Iorio MV, Ferracin M, Liu CG, Veronese A, Spizzo R, Sabbioni S, Magri E, Pedriali M, Fabbri M, Campiglio M, Menard S, Palazzo JP, Rosenberg A, Musiani P, Volinia S, Nenci I, Calin GA, Querzoli P, Negrini M, Croce CM: MicroRNA gene expression deregulation in human breast cancer. Cancer Res 2005, 65:7065-7070.

19. Si ML, Zhu S, Wu H, Lu Z, Wu F, Mo YY: miR-2I -mediated tumor growth. Oncogene 2007, 26:2799-2803.

20. Zhu S, Si ML, Wu H, Mo YY: MicroRNA-2I Targets the tumor suppressor gene Tropomyosin I (TPMI). J Biol Chem 2007, 282:|4328-|4336. 
21. Meng F, Henson R, Lang M, Wehbe H, Maheshwari S, Mendell JT, Jiang J, Schmittgen TD, Patel T: Involvement of human micro-RNA in growth and response to chemotherapy in human cholangiocarcinoma cell lines. Gastroenterology 2006, 130:21 I3-2129.

22. Tran N, McLean T, Zhang X, Zhao CJ, Thomson JM, O'brien C, Rose $B$ : MicroRNA expression profiles in head and neck cancer cell lines. Biochem Biophys Res Commun 2007, 358:12-I7.

23. Costinean S, Zanesi N, Pekarsky Y, Tili E, Volinia S, Heerema N, Croce CM: Pre-B cell proliferation and lymphoblastic leukemia/high-grade lymphoma in $E(m u)-m i R I 55$ transgenic mice. Proc Natl Acad Sci USA 2006, 103:7024-7029.

24. Fulci V, Chiaretti S, Goldoni M, Azzalin G, Carucci N, Tavolaro S, Castellano L, Magrelli A, Citarella F, Messina M, Maggio R, Peragine N, Santangelo S, Mauro FR, Landgraf $P$, Tuschl T, Weir DB, Chien M, Russo J], Ju J, Sheridan R, Sander C, Zavolan M, Guarini A, Foa R, Macino G: Quantitative technologies establish a novel microRNA profile of chronic lymphocytic leukemia. Blood 2007, 109:4944-4951.

25. Roldo C, Missiaglia E, Hagan JP, Falconi M, Capelli P, Bersani S, Calin GA, Volinia S, Liu CG, Scarpa A, Croce CM: MicroRNA expression abnormalities in pancreatic endocrine and acinar tumors are associated with distinctive pathologic features and clinical behavior. I Clin Oncol 2006, 24:4677-4684.

26. Felli N, Fontana L, Pelosi E, Botta R, Bonci D, Facchiano F, Liuzzi F, Lulli V, Morsilli O, Santoro S, Valtieri M, Calin GA, Liu CG, Sorrentino A, Croce CM, Peschle C: MicroRNAs $22 I$ and 222 inhibit normal erythropoiesis and erythroleukemic cell growth via kit receptor down-modulation. Proc Natl Acad Sci USA 2005, 102: $18081-18086$

27. He H, Jazdzewski K, Li W, Liyanarachchi S, Nagy R, Volinia S, Calin GA, Liu CG, Franssila K, Suster S, Kloos RT, Croce CM, de la Chapelle $A$ : The role of microRNA genes in papillary thyroid carcinoma. Proc Natl Acad Sci USA 2005, 102:19075-19080.

28. Pallante $\mathrm{P}$, Visone R, Ferracin M, Ferraro A, Berlingieri MT, Troncone G, Chiappetta G, Liu CG, Santoro M, Negrini M, Croce CM, Fusco A: MicroRNA deregulation in human thyroid papillary carcinomas. Endocr Relat Cancer 2006, 13:497-508.

29. Ciafre SA, Galardi S, Mangiola A, Ferracin M, Liu CG, Sabatino G, Negrini M, Maira G, Croce CM, Farace MG: Extensive modulation of a set of microRNAs in primary glioblastoma. Biochem Biophys Res Commun 2005, 334:135I-1358.

30. Pekarsky Y, Santanam U, Cimmino A, Palamarchuk A, Efanov A, Maximov V, Volinia S, Alder H, Liu CG, Rassenti L, Calin GA, Hagan JP, Kipps T, Croce CM: Tcll expression in chronic lymphocytic leukemia is regulated by miR-29 and miR-I8I. Cancer Res 2006, 66:11590-11593.

31. Mott JL, Kobayashi S, Bronk SF, Gores GJ: mir-29 regulates Mcl-I protein expression and apoptosis. Oncogene 2007, 26:6I33-40.

32. Bandres E, Cubedo E, Agirre X, Malumbres R, Zarate R, Ramirez N, Abajo A, Navarro A, Moreno I, Monzo M, Garcia-Foncillas J: Identification by Real-time PCR of I 3 mature microRNAs differentially expressed in colorectal cancer and non-tumoral tissues. Mol Cancer 2006, 5:29.

33. Akao Y, Nakagawa Y, Naoe T: MicroRNAs I43 and I45 are possible common onco-microRNAs in human cancers. Oncol Rep 2006, 16:845-850

34. Laneve P, Di Marcotullio L, Gioia U, Fiori ME, Ferretti E, Gulino A Bozzoni I, Caffarelli $E$ : The interplay between microRNAs and the neurotrophin receptor tropomyosin-related kinase $C$ controls proliferation of human neuroblastoma cells. Proc Natl Acad Sci USA 2007, 104:7957-7962.

35. Chen $Y$, Stallings RL: Differential patterns of microRNA expression in neuroblastoma are correlated with prognosis, differentiation, and apoptosis. Cancer Res 2007, 67:976-983

36. Welch C, Chen Y, Stallings RL: MicroRNA-34a functions as a potential tumor suppressor by inducing apoptosis in neuroblastoma cells. Oncogene 2007, 26:5017-5022.

37. Chang TC, Wentzel EA, Kent OA, Ramachandran K, Mullendore M, Lee KH, Feldmann G, Yamakuchi M, Ferlito M, Lowenstein C], Arking DE, Beer MA, Maitra A, Mendell JT: Transactivation of miR-34a by p 53 broadly influences gene expression and promotes apoptosis. Mol Cell 2007, 26:745-752.

38. Nervi C, Fazi F, Rosa A, Fatica A, Bozzoni I: Emerging role for microRNAs in acute promyelocytic leukemia. Curr Top Microbiol Immunol 2007, 3 13:73-84.
39. Johnson SM, Grosshans H, Shingara J, Byrom M, Jarvis R, Cheng A, Labourier E, Reinert KL, Brown D, Slack FJ: RAS is regulated by the let-7 microRNA family. Cell 2005, 1 20:635-647.

40. Akao $Y$, Nakagawa $Y$, Naoe T: let-7 microRNA functions as a potential growth suppressor in human colon cancer cells. Biol Pharm Bull 2006, 29:903-906.

4I. Meng F, Henson R, Wehbe-Janek H, Smith H, Ueno Y, Patel T: The MicroRNA let-7a modulates interleukin-6-dependent STAT3 survival signaling in malignant human cholangiocytes. J Biol Chem 2007, 282:8256-8264.

42. Brueckner B, Stresemann C, Kuner R, Mund C, Musch T, Meister M, Sultmann $\mathrm{H}$, Lyko F: The human let-7a-3 locus contains an epigenetically regulated microRNA gene with oncogenic function. Cancer Res 2007, 67:1419-1423.

43. Mayr C, Hemann MT, Bartel DP: Disrupting the pairing between let-7 and Hmga 2 enhances oncogenic transformation. Science 2007, 3 I 5:1576-1579.

44. Lee YS, Dutta A: The tumor suppressor microRNA let-7 represses the HMGA2 oncogene. Genes Dev 2007, 21:1025-1030.

45. Hebert C, Norris K, Scheper MA, Nikitakis N, Sauk JJ: High mobility group $A 2$ is a target for miRNA-98 in head and neck squamous cell carcinoma. Mol Cancer 2007, 6:5.

46. Hatfield SD, Shcherbata HR, Fischer KA, Nakahara K, Carthew RW, Ruohola-Baker $\mathrm{H}$ : Stem cell division is regulated by the microRNA pathway. Nature 2005, 435:974-978.

47. Lu J, Getz G, Miska EA, Alvarez-Saavedra E, Lamb J, Peck D, SweetCordero A, Ebert BL, Mak RH, Ferrando AA, Downing JR, Jacks T, Horvitz HR, Golub TR: MicroRNA expression profiles classify human cancers. Nature 2005, 435:834-838.

48. Bottoni A, Zatelli MC, Ferracin M, Tagliati F, Piccin D, Vignali C, Calin GA, Negrini M, Croce CM, Degli Uberti EC: Identification of differentially expressed microRNAs by microarray: a possible role for microRNA genes in pituitary adenomas. J Cell Physiol 2007, 21 10:370-377.

49. Lee EJ, Gusev Y, Jiang J, Nuovo GJ, Lerner MR, Frankel WL, Morgan DL, Postier RG, Brackett DJ, Schmittgen TD: Expression profiling identifies microRNA signature in pancreatic cancer. Int J Cancer 2007, I 20: 1046-1054

50. Takamizawa J, Konishi H, Yanagisawa K, Tomida S, Osada H, Endoh H, Harano T, Yatabe Y, Nagino M, Nimura Y, Mitsudomi T, Takahashi $\mathrm{T}$ : Reduced expression of the let-7 microRNAs in human lung cancers in association with shortened postoperative survival. Cancer Res 2004, 64:3753-3756.

5I. Yanaihara N, Caplen N, Bowman E, Seike M, Kumamoto K, Yi M, Stephens RM, Okamoto A, Yokota J, Tanaka T, Calin GA, Liu CG, Croce CM, Harris CC: Unique microRNA molecular profiles in lung cancer diagnosis and prognosis. Cancer Cell 2006, 9:189-198.

52. Bloomston M, Frankel WL, Petrocca F, Volinia S, Alder H, Hagan JP, Liu CG, Bhatt D, Taccioli C, Croce CM: MicroRNA expression patterns to differentiate pancreatic adenocarcinoma from normal pancreas and chronic pancreatitis. JAMA 2007, 297: $1901-1908$

53. Cho WC: Contribution of oncoproteomics to cancer biomarker discovery. Mol Cancer 2007, 6:25.

54. Cho WC, Cheng $\mathrm{CH}$ : Oncoproteomics: current trends and future perspectives. Expert Rev Proteomics 2007, 4:40I-4I0.

55. Cho WC: $\mathbf{A}$ future of cancer prevention and cures: highlights of the Centennial Meeting of the American Association for Cancer Research. Ann Oncol 2007. doi: 10.1093/annonc/mdm335 